\title{
sciendo
}

\author{
ANNA BARTKO, ANNA ZAGAJA, JAKUB PAWLIKOWSKI
}

\section{Human Milk Banks - biobanking for preterms and newborns}

\begin{abstract}
Breast milk banks are specialized hospital-located laboratories. Their role is to provide breast milk to newborns and infants who, for various reasons, cannot be fed with their mother's milk. They are an inseparable part of intensive neonatal care units and an element of the mother and child care system. They are financed by hospitals in which they operate. Milk is obtained from donors, thoroughly examined, pasteurized and passed directly to children in need. Food recipients are mainly premature babies in the neonatal intensive care unit. As proven by numerous scientific studies, breast milk is the most appropriate food for newborns and infants. Breast milk is also recommended by Polish, foreign and international organizations and institutions involved in nutritional problems of children.

There are 226 Breast Milk Banks in Europe (first organized in 1909 in Vienna) and the organization of additional 16 is planned. In Poland there are only 9 banks and two more are in the organizational phase. Breast milk banks in Poland operate on the basis of in-hospital regulations. The European Association of Milk Banks strives to unify the procedures of conduct in all units, including Poland.
\end{abstract}

Keywords: Breast Milk Bank, lactation, preterm baby, milk donors.

DOI: $10.2478 /$ pjph-2021-0016

\section{INTRODUCTION}

Breastfeeding and breast milk is the healthiest form of nutrition for all newborns and infants; both healthy and sick. Experts from around the world in the field of children's health and nutrition including the World Health Organization (WHO), the European Society for Pediatric Gastroenterology Hepatology and Nutrition (ESPGHAN), the United Nations International Children's Emergency Fund (UNICEF) and the American Academy of Pediatrics (AAP) recommend that children should be fed only breast milk for the first six months of their life, followed by a gradual extension of the diet. The maximum age limit for breastfeeding has not been established and it can be continued as long as the mother and child want it. Breast milk is proven to have immunological and anti-inflammatory properties and to stimulate the child's development not only during the feeding period, but also during the child's whole life. Despite numerous beneficial properties, breast milk may pose a risk when administered differently than directly from the breast. Therefore, in order to increase the safety of children receiving donor's milk, standards for pumping, storage, transport and feeding of breast milk were developed. If natural feeding faces obstacles, special support and professional lactation counseling is advised. Preterm labor, i.e. labor before the 37 th week of pregnancy, is a serious cause of the impossibility of breastfeeding. Paradoxically, for premature newborns breast milk is of therapeutic importance, although because of lactation problems, they are most prone to be bottle fed. Premature babies are given about 10-20 drops of milk (1-2 ml) during one feeding while newborns receive about $3 \mathrm{ml}$. Breast milk contains active ingredients, antibodies and stem cells that favorably affect the whole body's development. It is the food best suited to newborn's needs [1].

Approximately 15 million of premature babies are born annually and this number is growing year by year. Advances in medical technology enabled the rescue of an increasing number of children born with very low birth weight. All experts' committees recommend breast feeding for premature babies as it reduces the incidence of many diseases of the neonatal period. The composition of breast milk differs between women and depends on many factors.

The newborns' growth curve reflects infant's diet; whether they are fed with mother's milk, on the composition of the milk, on genetic predispositions, prematurity, and presence of diseases or previous infections in the first weeks after delivery. Long-term prognosis varies among children born prematurely and depends on the birth term; premature babies are exposed to insulin resistance and metabolic disorders in adulthood. Approximately $40 \%$ of premature infants have psychomotor disorders at the age of 5 . Increased growth in this period may result in higher susceptibility to metabolic diseases [2].

Milk biobanks are associated in The European Milk Bank Association (EMBA). EMBA is a non-profit organization founded in 2010. Its headquarters are located in Milan, Italy 
and the current president (2015-2018) is French Professor Jean-Charles Picaud. EMBA aims to promote Breast Milk Banks and to promote cooperation between banks all across Europe. What is more, the Association supports and promotes research aimed at increasing the knowledge about Milk Banks. Currently EMBA brings together 226 Breast Milk Banks in Europe, including nine in Poland. Active cooperation of the Breast Milk Bank Foundation with EMBA allows updating knowledge and exchanging international experience [3].

\section{Milk donors}

Mother's milk should always be the first choice in feeding newborns and infants. In a situation where mother's milk is impossible to obtain, administration of tested milk from the bank is a beneficial alternative, especially for sick children. Many women who are lactating, produce more milk than is necessary to feed their own child and for these mothers, donating the access milk into the Breast Milk Bank (BMB) may become a desired course of action. Milk is donated to banks on a voluntary basis, however to become a donor one must meet stringent health criteria and comply with established procedures related to food intake [4].

Recruitment of donors occurs in BMBs. The first stage of recruitment is the collection of epidemiological and environmental data and blood tests for hepatitis B, C, HIV and syphilis. Lactation is also evaluated to see whether the mother has adequate food surplus, so that she can donate her milk to the bank without harming her own child. The food is evaluated in terms of microbiological purity and nutritional value. If a woman passes this stage successfully, she becomes an honorary donor. When being a donor, she is obliged to undergo routine blood tests in order to rule out the risk of infection and to comply with hygiene rules when collecting, portioning and storing milk. Donors are usually women aged 25-35 who inhabit big cities. More than half of them had previous experience in breastfeeding. Milk donation cannot be a source of financial income, however, knowing that through donation it is possible to help other children restore health or even save lives is a source of satisfaction [4].

A mother who did not decide to become a donor but has supplies of frozen milk can donate them to the milk bank for scientific purposes. Due to the bank's procedures, food from an inexperienced donor cannot be given to sick children; however it can be used by scientists to develop knowledge about the value of natural milk [1].

Parents of premature newborns must consent to give their child pasteurized milk from the Breast Milk Bank. What is interesting, according to studies conducted in 2017, parents are more prone to donate milk than to give the donated milk to their children. Same studies indicate that $29 \%$ of the respondents would be willing to donate milk to the milk bank and as many as $36 \%$ would give such milk to their child [5].

None the less, in the first place, natural milk is given to hospitalized children prematurely born and with severe illnesses. If a newborn is in this group and there is no milk bank in the nearest vicinity, it is possible to contact the Regional Milk Bank through the leading physician and find out about the possibility of receiving milk. If the mother is not able to breastfeed, a healthy newborn can receive natural milk from the surplus left from the bank's resources. Each case is evaluated on an individual basis, in the bank that corresponds to the mother's place of residence or the nearest Bank [1].
Pregnant women learn about the possibility of sharing food when they are admitted to the obstetric wards in the hospital units where Breast Milk Banks function. Women get all the necessary information about the activities of the bank. One donor can collect approximately 10 liters of milk in two weeks. The food is divided into small portions, exactly described and frozen in bottles, which are obtained from the bank. In 2017, the Opolski Breast Milk Bank, after one year from the beginning of its activity, managed to collect 360 liters of breast milk, all from 39 donors. This food was given to 105 small patients. In addition, 290 milk composition tests were performed at the bank at that time [1].

Research conducted in 2015 reveals the need for frequent and professional lactation consultancy for women who are breastfeeding. It also proves that socio-economic factors and inappropriate incentives have a negative impact on the duration of breastfeeding whereas the promotion of benefits and feeding techniques influences the length of natural feeding. The same research points to the need of creating guidelines for successful feeding [6].

\section{Pasteurization process}

A milk bank consists of two main rooms: a lactation room and a laboratory. Each laboratory should be equipped with a milk composition tester, a pasteurizer, a homogenizer, a refrigerator and freezers. Milk pasteurization takes place in a semiautomated manner. Milk is pasteurized using the Holter method, which is based on keeping it in a temperature of $62.5^{\circ} \mathrm{C}$ for 30 minutes. The temperature is controlled in a test bottle, as temperature variations cannot exceed $\pm 0.5^{\circ} \mathrm{C}$. The second stage is a quick cooling to $4{ }^{\circ} \mathrm{C}$, the bottles should be manually transferred to the cooling chamber, which guarantees microbiological purity. After the end of the cycle, the pasteurization process is controlled by means of a computer program. Afterwards the milk is frozen to $-20{ }^{\circ} \mathrm{C}$. The pasteurization process kills all viruses and bacteria. The milk is then stored at a temperature of $4-8{ }^{\circ} \mathrm{C}$ and remains virus and bacteria free for at least 24 hours. Milk stored in freezers may stay in them for up to 3 months; however the demand is so high that it is used on a regular basis. Thanks to accurate documentation and using bar codes on each portion of milk, it is possible to track its route between donor and recipient. To ensure maximum safety, Milk Banks are run and managed by suitably trained medical staff [7].

\section{Milk banks in Poland}

Lactation activity in Poland can be divided into three periods. The first of them is based on facilities established in 1904 called Kropla Mleka [Eng. A drop of Milk]. These facilities operated in bigger cities and their goal was to pasteurize cow milk for newborns. The second period was lactaria offering pasteurized female milk. They, in turn, operated in hospital pediatric wards. The first batch of food from a lactarium was administered in 1981. The last laktarium operating within the Polish Mother's Memorial Hospital in Łódź ended its activity in 2005. The third period is based on contemporary Breast Milk Banks. Currently, there is an increase in the interest in Breast Milk Banks.

Milk banks in Poland are not under any legal provisions that regulate the possibility of sharing women's milk. Along with the change of the Constitution several decades ago, the provisions on the activities of lactarias ceased to apply. Women's 
milk banks operating today do so on the basis of in-hospital regulations based on the "Mamy mleko dla malucha" (In Polish "Mamy" means both "mom's" and "we have" therefore it is a word play which means either "Mom's milk for premature babies" or "We have milk for premature babies") program, which was created by the Breast Milk Bank Foundation. Thanks to the introduction and popularization of this program, it was possible to standardize the documentation and operating principles of all Milk Bank branches. Currently, there are 9 Breast Milk Banks under the auspice of the Foundation in Poland, two are in the organization phase. An exception is the Breast Milk Bank in Ruda Śląska created together with specialists from the Scandinavian countries [8].

\section{CONCLUSION}

Breastfeeding and breast milk is the best method of feeding premature babies and infants because it is the food most suited to their needs. If the mother is unable to feed her baby for whatever reason, the best solution is to use pasteurized milk from a Breast Milk Bank [9]. Breast Milk Banks are an inseparable element of mother and child care and an invaluable part of the neonatal unit. Milk banks require the involvement of various specialists including those from the neonatology, gynecology and midwifery departments, as well as laboratory employees, microbiologists and diagnostics. World-wide research shows a downward trend in neonatal mortality and the incidence of necrotizing enterocolitis (NEC) using human milk from Human Milk Bank [10].

The biggest obstacle in the Polish society is low awareness of mothers about the value of natural food, low knowledge about Breast Milk Banks and a small number of donors. In the environment there is a great need to educate pregnant women about the possibility of giving milk to the bank, because the demand among hospitalized children is overwhelming [5].

Over the past decade, there has been an intensive worldwide development of milk bank institutions and the standardization of procedures regarding the collection, processing, storage and distribution of human milk has been established. Despite many legal gaps regarding sharing of women's milk, Poland is quite a dynamically developing country in terms of milk banks. Cooperation with the European Milk Bank Association and raising professional qualifications of the staff employed in the bank ensures high quality of treatment and full safety [7]. There is, however, insufficient knowledge about Breast Milk Banks in the environment and there is a great need to educate pregnant women about the possibility of donating their milk [5].

Considering the needs of premature babies from all over Poland, as well as the fact that mothers of such newborns are the main source of surplus milk, it is possible to estimate the needs of Polish banks. Taking this need into consideration, each neonatal intensive care unit should have a breast milk bank of its own. There should be approximately 150 such units in Poland, out of which about 35 should be additionally equipped with equipment allowing to analyze milk (third level of reference), and about 15 banks should be regional banks with much wider possibilities of research and providing food for the needs of other hospitals. The launch of so many branches in Poland would be associated with high initial costs; however, as estimated, this cost would be three times smaller than the amount spent annually on reimbursement of artificial mixtures by the National Health Fund [11].

\section{REFERENCES}

1. http://bankmleka.pl/ (access: 12.08.2018)

2. Boquien CY. Human milk: an ideal food for nutrition of preterm newborn. Front Pediatr. 2018;6:295.

3. http://europeanmilkbanking.com/ (access: 04.08.2018)

4. Wilińska M, Kowal A, Baranowska E. Kim są dawczynie pokarmu do banku mleka kobiecego? Stand Med Pediatr. 2016;13:204.

5. Szyszka M, Dębska S, Bączek G, Dmoch-Gajzlerska E. Wiedza i opinia kobiet na temat banków mleka kobiecego. Położ Nauka Prakt. 2017;1(37):59.

6. Figueiredo M, Buenno M, Ribeiro C, et al. Human milk bank: breastfeeding counseling and the duration of exclusive breastfeeding. J Hum Growth Dev. 2015;25(2):204-10

7. Wilińska M, Borszewska-Kornacka M, Wesołowska A, et al. Bank mleka kobiecego w Polsce - pierwsze doświadczenia. Stand Med Pediatr. 2013;10:549.

8. Wesołowska A, Paseczna I, Studniczek A. Społeczny aspekt funkcjonowania banków mleka kobiecego. Stand Med Pediatr. 2017;14:159.

9. Bharadva K, Tiwari S, Mishra S, Mukhopadhyay K, et al. Human milk banking guidelines. Indian Pediatr. 2014;51:469-74.

10. Adhisivam B, Vishnu Bhat B, Banupriya N, et al. Impact of human milk banking on neonatal mortality, ecrotizing enterocolitis, and exclusive breastfeeding - experience from a tertiary care teaching hospital, south India. J Matern Fetal Neonatal Med. 2018;32(6):902-5.

11. Knypl K. Przyszłość banków mleka kobiecego w Polsce. Gazeta dla Lekarzy. 2015;6:20.

\section{Corresponding author}

Anna Bartko

Department of Humanities and Social Medicine, Medical University of Lublin 7 Chodźki St., 20-093 Lublin

E-mail: cisek.anna@wp.pl

tel: +48 515556991 